\section{Received}

May, $5^{\text {th }} 2021$
Accepted

Jun, $23^{\text {th }} 2021$
Published

Jun, $27^{\text {th }} 2021$

\title{
The Effect of Information Services Toward Confidence Students' in Expressing Opinions
}

\author{
Dina Hidayati Hutasuhut ${ }^{*}$, Muhammad Noer Fadlan \\ Universitas Muslim Nusantara Al-Washliyah, North Sumatra, Indonesia. \\ *)E-mail: dinahidayati@umnaw.co.id
}

\begin{abstract}
This research aims to determine the effect of information services on confidence in expressing opinions in student online lectures. The method used in this study is a quantitative method. This type of research is a quasi-experimental with the type of Pre test-post test one group design. The subjects in this study were 30 students in semesters 1 and 3 who had low confidence in expressing their opinions. The instrument used is a self-confidence scale in expressing opinions. Instruments are given before and after the implementation of information services. Data were analyzed using the Wilcoxon test. Pre-test data in the experimental group obtained an average $=73.5$ while the post-test data obtained an average $=119.30$. This data is in accordance with the Wilcoxon level test obtained Jcount $=132$ while Jtable $=105$. Based on the critical value table $\mathrm{J}$ for the Wilcoxon marked level test for $n=30,=0.05$ the hypothesis is accepted. That is, there is a significant effect of providing information services on confidence in expressing opinions on online student recovery.
\end{abstract}

Keywords: Information Services; Confidence Expressing Opinions; Students; Online.

\begin{abstract}
Abstrak
Penelitian ini bertujuan untuk mengetahui pengaruh layanan informasi terhadap kepercayaan diri dalam mengemukakan pendapat pada perkuliahan daring mahasiswa Metode yang digunakan dalam penelitian ini adalah metode kuantitatif. Jenis penelitian ini adalah Quasi experimental dengan jenis Pre test-post test one group design. Subjek dalam penelitian ini adalah 30 orang mahasiswa pada semester 1 dan 3 yang kepercayaan diri dalam mengemukakan pendapatnya rendah. Instrumen yang digunakan adalah skala kepercayaan diri dalam mengemukakan pendapat. Instrumen diberikan sebelum dan sesudah pelaksanaan layanan informasi. Data dianalisis menggunakan uji Wilcoxon. Data pre-test pada kelompok eksperimen diperoleh rata-rata $=73,5$ sedangkan data post-test diperoleh rata-rata $=119,30$. Data ini sesuai dengan uji jenjang Wilcoxon diperoleh Jhitung $=132$ sedangkan Jtabel $=105$. Berdasarkan tabel nilai kritis $\mathrm{J}$ untuk uji jenjang bertanda Wilcoxon untuk $n=30, a=0,05$ hipotesis diyatakan diterima. Artinya, Terdapat pengaruh signifikan pemberian layanan informasi terhadap kepercayaan diri dalam mengemukakan pendapat Pada perkulihan Daring Mahasiswa.
\end{abstract}

Kata Kunci: Layanan Informasi; Kepercayaan Diri Mengemukakan Pendapat; Mahasiswa; Daring. 


\section{PENDAHULUAN}

Virus Corona mulai masuk ke Indonesia sejak 2 Maret 2020. Presiden Joko Widodo mengumumkan bahwa Indonesia sudah menjadi salah satu negara yang warganya positif terkena virus corona. Hal tersebutlah yang membuat pemerintah mengeluarkan kebijakan pembatasan sosial untuk mengurangi persebaran virus korona di Indonesia. Terhitung sejak tanggal 23 Maret 2020, banyak sekolah, kampus, tempat ibadah, bahkan para pekerja yang mengeluarkan kebijakan untuk bekerja atau belajar dari rumah (Ihsanuddin, 2020).

Belajar dari rumah untuk mahasiswa berarti kuliah dari rumah, menggantikan kuliah tatap muka dengan kuliah daring atau online. Namun hal ini tidak mengurangin semangat mahasiswa . Kuliah daring dilakukan dengan menggunakan beberapa aplikasi berupa group what'up, google classcroom dan zoom (Prasetyaningtyas, 2021). Dosen tetap memberikan materinya dan mahasiswa diminta untuk mengajukan pertanyaan atau memberikan pendapat terkait materi yang di berikan. Namun tetap saja beberapa Mahasiswa masih ada yang belum berani atau tidak percaya diri untuk mengeluarkan pendapat nya.

Menurut Kamus Istilah Bimbingan dan Konseling Percaya diri adalah kondisi mental atau psikologis diri yang memberikan keyakinan kuat pada dirinya". Orang yang tidak percaya diri memiliki konsep diri negatif kurang percaya pada kemampuannya (Thantaway, 2005). Rasa percaya diri juga berpengaruh terhadap kemampuan bersosialisasi anak dalam belajar. Salah satunya adalah dalam mengemukakan pendapat saat belajar sedang berlangsung ataupun berdiskusi.

Berdasarkan hasil observasi awal selama proses kuliah daring cukup banyak mahasiswa mengalami kesulitan dalam mengemukakan pendapat, misalnya pada saat mahasiswa diminta untuk menjawab pertanyaan yang diberikan sebagian besar mahasiswa hanya diam saja sehigga dosen harus menjawab pertanyaannya sendiri .

Dalam membantu siswa meningkatkan kepercayaan diri dalam mengemukakan pendapat, maka perlu diberi layanan informasi. Layanan informasi merupakan satu layanan yang berupaya memenuhi kekurangan individu akan informasi yang mereka perlukan. Layanan informasi juga bermakna usaha-usaha untuk membekali siswa dengan pengetahuan serta pemahaman tentang lingkungan hidupnya dan tentang proses perkembangan kepribadiannya. Dengan layanan informasi mahasiswa dapat memahami tentang bagaimana meningkatkan kepercaayaan diri, penyebab, dan cara mengatasinya dan diberikan melalui media yang menarik agar mereka mudah memahami dan tidak bosan.

Beberapa penelitian tentang pemberian layanan informasi untuk meningkatkan kepercayaan diri telah dilakukan (Aristiani, 2016; Mahdalena, 
2019). Namun belum ditemukan penelitian terkait pemberian layanan informasi untuk mengikatkan kepercayaan diri mengemukakan pendapat dalam pembelajaran daring. Maka dari itu, Berdasarkan uraian di atas maka peneliti terdorong untuk melakukan penelitian dengan judul Pengaruh Pemberian Layanan Informasi Terhadap Kepercayaan Diri Dalam Mengemukakan Pendapat pada Perkuliahan daring Mahasiswa.

\section{METODE}

Jenis penelitian yang digunakan yaitu penelitian kuantitatif dengan pendekatan eksperimen semu melalui model one group pretest-posttest design. Pada design ini, diawali dengan sebuah tes awal (pretest), kemudian diberi perlakuan (treatment) sebanyak 5 kali pertemuan tatap muka secara daring. Peneliti sebagai pelaksana layanan informasi, dan mahasiswa yang menjadi sampel penelitian menjadi peserta penelitian. Informasi yang disampaikan oleh peneliti berkaitan dengan kepercayaan diri dalam mengemukakan pendapat mahasiswa. Penelitian kemudian diakhiri dengan sebuah tes akhir (posttest). Sampel dalam penelitian ini adalah mahasiswa semester I dan III Program Studi Bimbingan Konseling Universitas Muslim Nusantara (UMN) Al-Wasliyah Medan yang berjumlah 30 orang mahasiswa terdiri dari 17 mahasiswa semester 1 dan 13 mahasiswa semester III. Teknik pengambilan sampel dalam penelitian ini adalah purposive sampling (sampel bertujuan) yang dilakukan dengan menentukan hasil pretest yang terendah di kelas dengan teknik pengambilan data menggunakakan angket Kepercayaan Diri Dalam Mengemukakan Pendapat yang berpedoman pada skala Likert yang telah dilakukan uji validitas dan reliabilitasnya. Pelaksanaan Selanjutnya, Teknik analisis data menggunakan Uji Wilcoxon Test dengan bantuan perangkat lunak Statistical Product and Service Solutions (SPSS) Versi 17.

\section{HASIL PENELITIAN DAN PEMBAHASAN Deskripsi Data Hasil Penelitian}

Setelah dilakukan penyebaran skala, maka selanjutnya adalah memberikan skor pada skala dengan menjumlahkan nilai-nilai yang diperoleh setiap Mahasiswa. Setelah diketahui jumlah skor angket kepercayaan diri dalam mengemukakan pendapat maka dilakukan pengkategorian sebagai berikut:

Tabel 1. Kriteria Kepercayaan Diri Dalam Mengemukakan Pendapat

\begin{tabular}{cc}
\hline Interval & Kriteria \\
\hline $37-74$ & Rendah \\
$75-111$ & Sedang \\
$112-148$ & Tinggi \\
\hline
\end{tabular}

\section{Hasil Pre-test Kepercayaan Diri Dalam Mengemukakan Pendapat}


Data diperoleh dari hasil Pre-Test kepercayaan diri dalam mengemukakan pendapat pada 30 orang subjek, diperoleh hasil sebagai berikut:

Tabel 2. Deskripsi Data Penelitian Pre-test dan Post-test

\begin{tabular}{cccc}
\hline No & Interval & Pre-Test & Post-Test \\
\hline 1 & Rendah & 15 & 0 \\
2 & Sedang & 14 & 6 \\
3 & Tinggi & 0 & 23 \\
\hline
\end{tabular}

\section{Data Hasil Analisis Pre-Test dan Post-Test Kepercayaan Diri dalam Mengemukakan Pendapat}

Berdasarkan hasil analisis pre-test dan post-test kepercayaan diri dalam mengemukakan pendapat yang dilakukan kepada 30 orang subjek, maka diperoleh hasil sebagai berikut:

Tabel 3. Analisa Data Pre-Test Dan Post-Test

\begin{tabular}{|c|c|c|c|c|c|}
\hline \multirow{2}{*}{ No. } & \multirow{2}{*}{ Responden } & \multirow{2}{*}{ Skor Pre test } & \multirow{2}{*}{ Skor Post Test } & \multicolumn{2}{|c|}{ Selisih Perubahan } \\
\cline { 5 - 6 } & & & Skor & \% \\
\hline 1 & AFS & 85 & 131 & 46 & 54,11 \\
\hline 2 & MAS & 77 & 140 & 63 & 81,81 \\
\hline 3 & FDS & 78 & 130 & 52 & 66,66 \\
\hline 4 & RFL & 91 & 131 & 40 & 43,95 \\
\hline 5 & ZSP & 84 & 131 & 47 & 55,95 \\
\hline 6 & MAF & 78 & 133 & 55 & 70,51 \\
\hline 7 & AKH & 80 & 135 & 55 & 68,75 \\
\hline 8 & TAZ & 66 & 134 & 68 & 103,03 \\
\hline 9 & MLL & 67 & 106 & 39 & 58,20 \\
\hline 10 & ARD & 68 & 134 & 66 & 97,05 \\
\hline 11 & LRP & 64 & 104 & 40 & 62,5 \\
\hline 12 & VER & 65 & 94 & 29 & 44,61 \\
\hline 13 & NSD & 69 & 106 & 37 & 53,62 \\
\hline 14 & WSY & 69 & 123 & 54 & 78,26 \\
\hline 15 & AZH & 65 & 115 & 50 & 76,92 \\
\hline 16 & TKP & 72 & 112 & 40 & 55,55 \\
\hline 17 & RAP & 72 & 119 & 47 & 65,27 \\
\hline 18 & KJH & 71 & 128 & 57 & 80,28 \\
\hline 19 & KAZ & 78 & 121 & 43 & 51,12 \\
\hline 20 & AAS & 68 & 122 & 54 & 79,41 \\
\hline 21 & RND & 79 & 126 & 47 & 59,49 \\
\hline 22 & DMW & 74 & 122 & 48 & 64,86 \\
\hline 23 & APA & 74 & 125 & 51 & 68,91 \\
\hline 24 & RYH & 63 & 110 & 47 & 74,60 \\
\hline 25 & ADA & 76 & 114 & 38 & 50 \\
\hline 26 & MMH & 111 & 119 & 8 & 7,20 \\
\hline 27 & AAM & 67 & 101 & 34 & 50,74 \\
\hline 28 & YRE & 78 & 122 & 44 & 56,41 \\
\hline & & & & \\
\hline & & & & & \\
\hline
\end{tabular}




\begin{tabular}{|c|c|c|c|c|c|}
\hline 29 & MSY & 83 & 114 & 31 & 37,34 \\
\hline 30 & JDA & 72 & 115 & 43 & 59,72 \\
\hline \multicolumn{2}{|c|}{ Jumlah Total } & $\mathbf{2 2 4 4}$ & $\mathbf{3 6 1 7}$ & $\mathbf{1 3 7 3}$ & $\mathbf{6 1 , 1 8}$ \\
\hline \multicolumn{2}{|c|}{ Nilai Tertinggi } & $\mathbf{1 1 1}$ & $\mathbf{1 4 0}$ & $\mathbf{2 9}$ & $\mathbf{1 0 3 , 0 3}$ \\
\hline \multicolumn{2}{|c|}{ Nilai Terendah } & $\mathbf{6 3}$ & $\mathbf{9 4}$ & $\mathbf{3 1}$ & $\mathbf{7 , 2 0}$ \\
\hline \multicolumn{2}{|c|}{ Rata-rata } & $\mathbf{7 4 , 8}$ & $\mathbf{1 2 0 , 5 6}$ & $\mathbf{4 5 , 7 6}$ & $\mathbf{6 9 , 2 7}$ \\
\hline
\end{tabular}

\section{Pengujian Hipotesis}

Pengujian hipotesis dilakukan dengan perhitungan uji jenjang bertanda Wilcoxon. Hasil uji jenjang betanda Wilcoxon yang dilakukan pada 30 orangresponden, hasilnya terdapat nilai terkecil yaitu 132, jadi J hitung $=132$, dengan $\alpha=0,05$ dan $n$ = 30 maka diperoleh nilai $\mathrm{J}$ tabel sebesar 105. Dari data tersebut terlihat bahwa Jhitung $>\mathrm{J}_{\text {Tabel }}$ dimana 132>105. Maka dapat disimpulkan bahwa "Ada Pengaruh Layanan Informasi Terhadap Kepercayaan Diri Dalam Mengemukakan Pendapat Pada Perkuliahan Daring Mahasiswa BK UMN AW dengan demikian hipotesis diterima.

\section{KESIMPULAN}

Berdasarkan hasil perhitungan hipotesis dengan uji Wilcoxon $\alpha=0,05$ dan n=30 maka diperoleh Jhitung $>$ J Tabel dimana $132>105$. Maka dapat dikatakan bahwa ada pengaruh dari layanan informasi terhadap kepercayaan diri dalam mengemukakan pendapat pada perkuliahan Daring Mahasiswa BK UMN AW Tahun Ajaran 2019/2020, dengan demikian hipotesis diterima.

Hasil secara keseluruhan dari data pre-test kepercayaan diri dalam mengemukakan pendapat sebelum pemberian layanan informasi diperoleh skor rata-rata sebesar 74,8 sedangkan data post-test kepercayaan diri dalam mengemukakan pendapat setelah pemberian layanan informasi diperoleh skor rata-rata sebesar 119,30. Maka dengan demikian terjadi selisih perubahan kepercayaan diri dalam mengemukakan pendapat diperoleh skor sebesar 45,76, artinya terjadi perubahan peningkatan kepercayaan diri dalam mengemukakan pendapat sebesar $69,27 \%$.

Dengan adanya pengaruh layanan informasi terhadap kepercayaan diri dalam mengemukakan pendapat, maka layanan informasi merupakan salah satu layanan dalam BK yang mampu meningkatkan kepercayaan diri dalam mengemukakan pendapat pada mahasiswa yang berkenaan dengan kejujuran, rasa tanggungjawab, semangat belajar, disiplin diri, kegigihan, apresiasi terhadap kebinekaan, semangat berkontribusi dan optimis.

Berdasarkan kesimpulan di atas, maka sebagai tindak lanjut penelitian ini diharapkan bagi peneliti selanjutnya apabila akan melakukan penelitian yang 
sama untuk lebih memperhatikan faktor-faktor yang mempengaruhi responden secara individual sesuai dengan variable yang diteliti dan indikator yang ada.

\section{REFERENSI-REFERENSI}

Aristiani, R. (2016). Meningkatkan Percaya Diri Siswa Melalui Layanan Informasi Berbantuan Audiovisual. Jurnal Konseling Gusjigang, 2(2), 182-189. https:/ / doi.org/10.24176/jkg.v2i2.717

Ihsanuddin. (2020). Jokowi Umumkan Dua Orang di Indonesia Positif Corona. Kompas.Com.

Mahdalena, M. (2019). Layanan Informasi Meningkatkan Percaya Diri Siswa Dalam Mengemukakan Pendapat di MAN 3 Banjarmasin. Jurnal Mahasiswa BK AnNur : Berbeda, Bermakna, Mulia, 5(2), 1. https://doi.org/10.31602/jmbkan.v5i2.2077

Prasetyaningtyas, S. (2021). Pelaksanaan Belajar dari Rumah (BDR) Secara Online Selama Darurat Covid-19 di SMP N 1 Semin. Jurnal Karya Ilmiah Guru, 5(1), 86-94.

Thantaway. (2005). Kamus Istilah Bimbingan dan Konseling. Kanisius. 